

\section{Wind Turbine Safety and Function Test Report for the Mariah Windspire Wind Turbine}

Arlinda Huskey, Amy Bowen, and Dave Jager

Prepared under Task No. WE10.2211

Technical Report NREL/TP-500-47496

July 2010

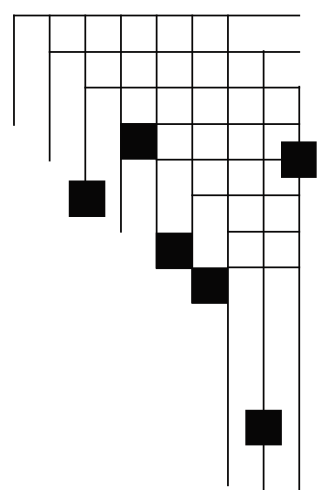




\section{NOTICE}

This report was prepared as an account of work sponsored by an agency of the United States government. Neither the United States government nor any agency thereof, nor any of their employees, makes any warranty, express or implied, or assumes any legal liability or responsibility for the accuracy, completeness, or usefulness of any information, apparatus, product, or process disclosed, or represents that its use would not infringe privately owned rights. Reference herein to any specific commercial product, process, or service by trade name, trademark, manufacturer, or otherwise does not necessarily constitute or imply its endorsement, recommendation, or favoring by the United States government or any agency thereof. The views and opinions of authors expressed herein do not necessarily state or reflect those of the United States government or any agency thereof.

Available electronically at http://www.osti.gov/bridge

Available for a processing fee to U.S. Department of Energy and its contractors, in paper, from:

U.S. Department of Energy

Office of Scientific and Technical Information

P.O. Box 62

Oak Ridge, TN 37831-0062

phone: 865.576 .8401

fax: 865.576 .5728

email: mailto:reports@adonis.osti.gov

Available for sale to the public, in paper, from:

U.S. Department of Commerce

National Technical Information Service

5285 Port Royal Road

Springfield, VA 22161

phone: 800.553.6847

fax: 703.605.6900

email: orders@ntis.fedworld.gov

online ordering: http://www.ntis.gov/ordering.htm 


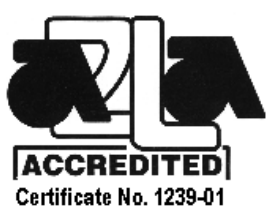

\section{Notice}

This report was prepared by the National Renewable Energy Laboratory (NREL), operated for the United States Department of Energy (DOE) by the Alliance for Sustainable Energy, LLC (Alliance), as an account of work sponsored by the United States government. The test results documented in this report define the characteristics of the test article as configured and under the conditions tested.

This report is provided "as is" and neither the government, Alliance, NREL, nor any of their employees makes any warranty, express or implied, including the warranties of merchantability and fitness for a particular purpose, or assumes any legal liability or responsibility for the accuracy, completeness, or usefulness of any such information disclosed in the report, or of any apparatus, product, or process disclosed, or represents that its use would not infringe privately owned rights.

Neither Alliance nor the United States government shall be liable for special, consequential, or incidental damages. Reference herein to any specific commercial product, process, or service by trade name, trademark, manufacturer, or otherwise does not necessarily constitute or imply its endorsement, recommendation, or favoring by the United States government or any agency thereof. The views and opinions of the authors expressed herein do not necessarily state or reflect those of the United States government or any agency thereof or Alliance.

NREL is a DOE Laboratory and, as an adjunct of the United States government, cannot certify wind turbines. The information in this report is limited to NREL's knowledge and understanding as of this date.

NREL is accredited by the American Association for Laboratory Accreditation (A2LA) and the results shown in this test report have been determined in accordance with the NREL's terms of accreditation unless stated otherwise in the report.

This report shall not be reproduced, except in full, without the written approval of Alliance or successor operator of NREL.

Approval By:

Arlinda Huskey, NREL Test Engineer Date

Approval By:

$$
\text { Jeroen van Dam, NREL Test Engineer Date }
$$




\section{List of Acronyms}

AWG

DOE

NREL

NWTC

SWT
American Wire Gauge

United States Department of Energy

National Renewable Energy Laboratory

National Wind Technology Center

small wind turbine 


\section{Table of Contents}

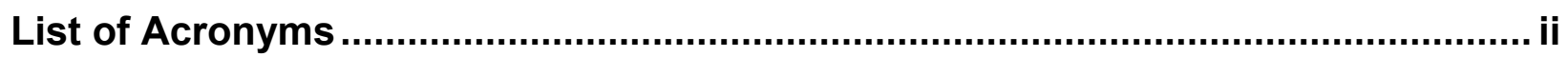

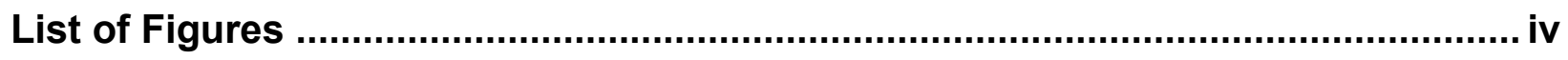

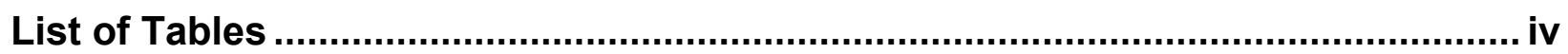

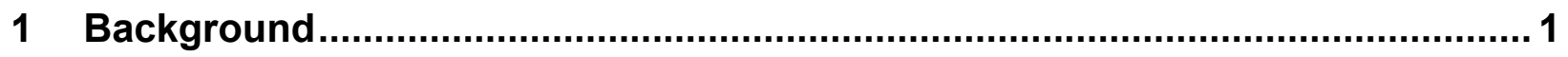

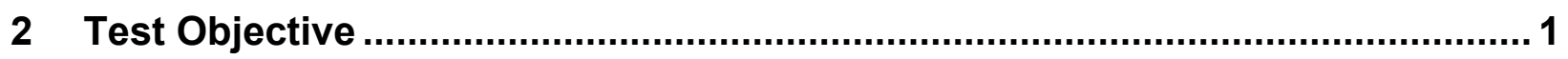

3 Description of Test Turbine and Setup .......................................................... 1

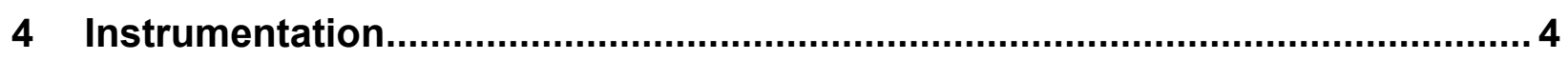

5 Procedure

5.1 Control and Protection System Functions.....................................................................................

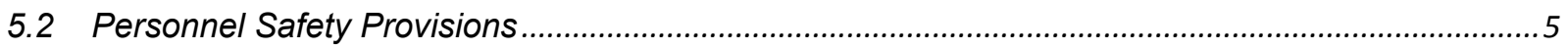

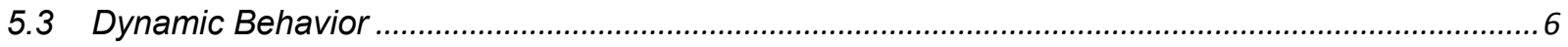

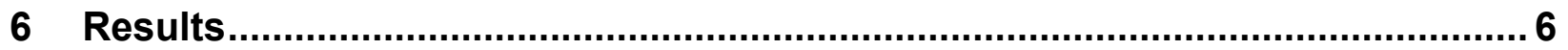

6.1 Control and Protection System Functions...................................................................................

6.2 Personnel Safety Provisions ................................................................................................................

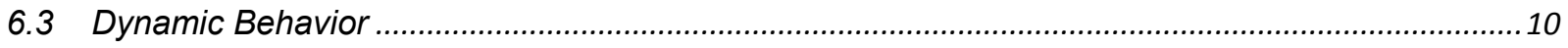

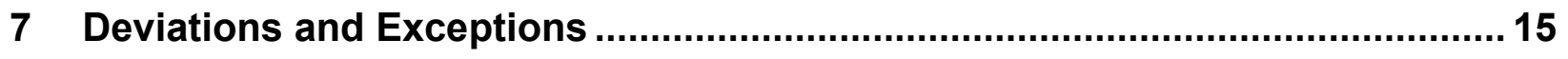

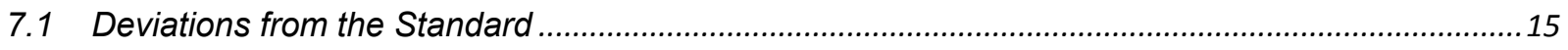

7.2 Exceptions to the NWTC Quality Assurance System...............................................................15

Appendix A. Instrument Calibration Sheets .......................................................... 16 


\section{List of Figures}

Figure 1. Windspire wind turbine at the NWTC test site ..............................................

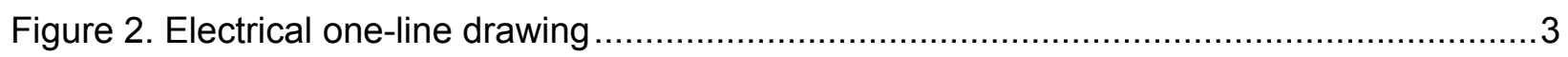

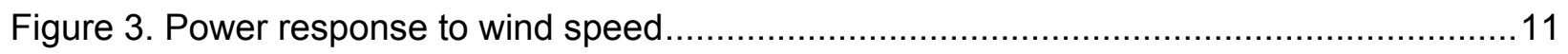

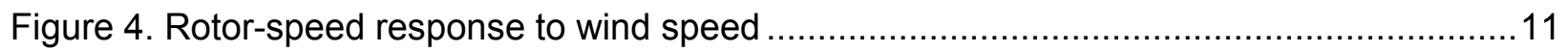

Figure 5. Normal start-up, wind speeds greater than cut-in ........................................... 12

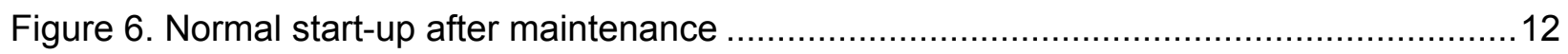

Figure 7. Normal shut down, winds decreasing below cut in ....................................... 13

Figure 8. Normal shut down, maintenance at design wind speed or greater ........................13

Figure 9. Emergency stop at wind speeds less than the design wind speed........................14

Figure 10. Emergency stop at design wind speed or greater .....................................14

\section{List of Tables}

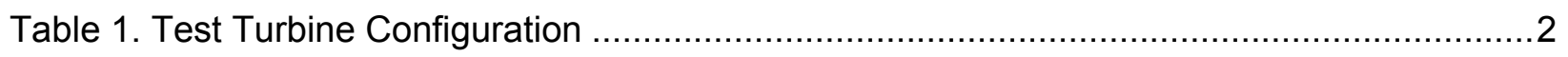

Table 2. Equipment List for Safety and Function Test ............................................... 4 


\section{Background}

This test was conducted as part of the U.S. Department of Energy's (DOE) Independent Testing project. This project was established to help reduce the barriers to wind energy expansion by providing independent testing results for small wind turbines (SWT). In total, five turbines were tested at the National Wind Technology Center (NWTC) as a part of this project. Safety and function testing is one of up to five tests performed on the turbines, including power performance, duration, noise, and power-quality tests. NWTC testing results provide manufacturers with reports that may be used to meet part of small wind turbine certification requirements.

The test equipment includes a Windspire wind turbine mounted on a monopole tower. L\&E Machine manufactured the turbine in the United States. The inverter was manufactured separately by Technology Driven Products in the United States. The system was installed by the NWTC site operations group with guidance and assistance from Mariah Power.

During this test, two configurations were tested on the same turbine. In the first configuration, the turbine inverter was optimized for power production. In the second configuration, the turbine inverter was set for standard power production. In both configurations, the inverter experienced failures. Tests from both of these configurations are included in the report, though each test was not performed on both configurations of the turbine. Testing on the Windspire was terminated before all of the planned safety and function tests could be completed.

\section{Test Objective}

The objective of this test was to:

- Verify whether the test turbine displays the behavior predicted in the design;

- Determine whether provisions relating to personnel safety are properly implemented; and

- Characterize the dynamic behavior of the wind turbine at rated wind speed and greater speeds.

The National Renewable Energy Laboratory (NREL) does not limit safety and function tests to features described in the wind turbine documentation, and NREL also inspects - possibly tests - and reports on features that are required by IEC 61400-2 and that might not be described in the wind turbine documentation. NREL conducted this test in accordance with Section 9.6 of the IEC standard, "Wind Turbines-Part 2: Design Requirements for Small Wind Turbines," IEC 61400-2, second edition, 2006-03.

\section{Description of Test Turbine and Setup}

The test turbine was a Mariah Power Windspire wind turbine. This turbine is a vertical axis, three-bladed, variable-speed, turbine with a rated power of 1-kW. Figure 1 shows the test 
turbine installed at the NWTC. Table 1 provides the key descriptive information of the test turbine.

Table 1. Test Turbine Configuration

\begin{tabular}{|l|l|}
\hline $\begin{array}{l}\text { Turbine manufacturer name } \\
\text { and address }\end{array}$ & $\begin{array}{l}\text { Mariah Power } \\
748 \text { S. Meadows Pkwy. A-9, } \\
\# 329 \\
\text { Reno, NV 89521 }\end{array}$ \\
\hline Model name & Windspire \\
\hline Serial number & 800021 \\
\hline Revision number & $1 \mathrm{P}$ \\
\hline Production date & 2008 \\
\hline Design nominal voltage at terminals (VAC) & 120 \\
\hline Maximum current at terminals (A) & 20 \\
\hline Design frequency at terminals (Hz) & 60 \\
\hline Small wind turbine (SWT) class & IV \\
\hline Design 50-year extreme wind speed, $\mathrm{V}_{\mathrm{e} 50}(\mathrm{~m} / \mathrm{s})$ & 42 \\
\hline Equivalent Rotor diameter (m) & 3.08 \\
\hline Hub height (vertical center of rotor) (m) & 6.10 \\
\hline Tower type & Tubular \\
\hline Rated electrical power (kW) & 1 \\
\hline $\begin{array}{l}\text { Rated wind speed (m/s) (slowest wind speed } \\
\text { at which turbine produces rated power) }\end{array}$ & 11.0 \\
\hline $\begin{array}{l}\text { Rated rotor speed (rpm) (slowest rotor speed } \\
\text { at which turbine produces rated power) }\end{array}$ & 180 \\
\hline Rotor speed range (rpm) & $0-500$ \\
\hline Fixed or variable pitch & Fixed \\
\hline Number of blades & 3 \\
\hline Blade pitch angle (deg) & 3 \\
\hline Blade make, type, serial number & Mariah Power, Airfoil, NA \\
\hline Description of control system (device \& software & Windspire 1.2G \\
\hline &
\end{tabular}

The Windspire wind turbine was installed at site 3.3C at the NWTC, which is located 8 miles south of Boulder, Colorado. The site's terrain primarily is flat with short vegetation. The test site has prevailing wind bearing 292 degrees relative to true north. For measurements requiring highly accurate wind-speed data, NREL used data obtained when the wind direction was between 132 degrees true to 323 degrees true. In this measurement sector-which was established in accordance with IEC 61400-12-1 - the influence of terrain and obstructions on the anemometer and turbine is slight.

Figure 2 shows the general electrical arrangement. The wire run from the base of the tower to the data shed is approximately 54 meters of \#12-2 American Wire Gauge (AWG) wire. Inside the data shed, on the turbine side of the transformer, the wire run is connected to a disconnect switch and a dedicated breaker in a breaker panel. 


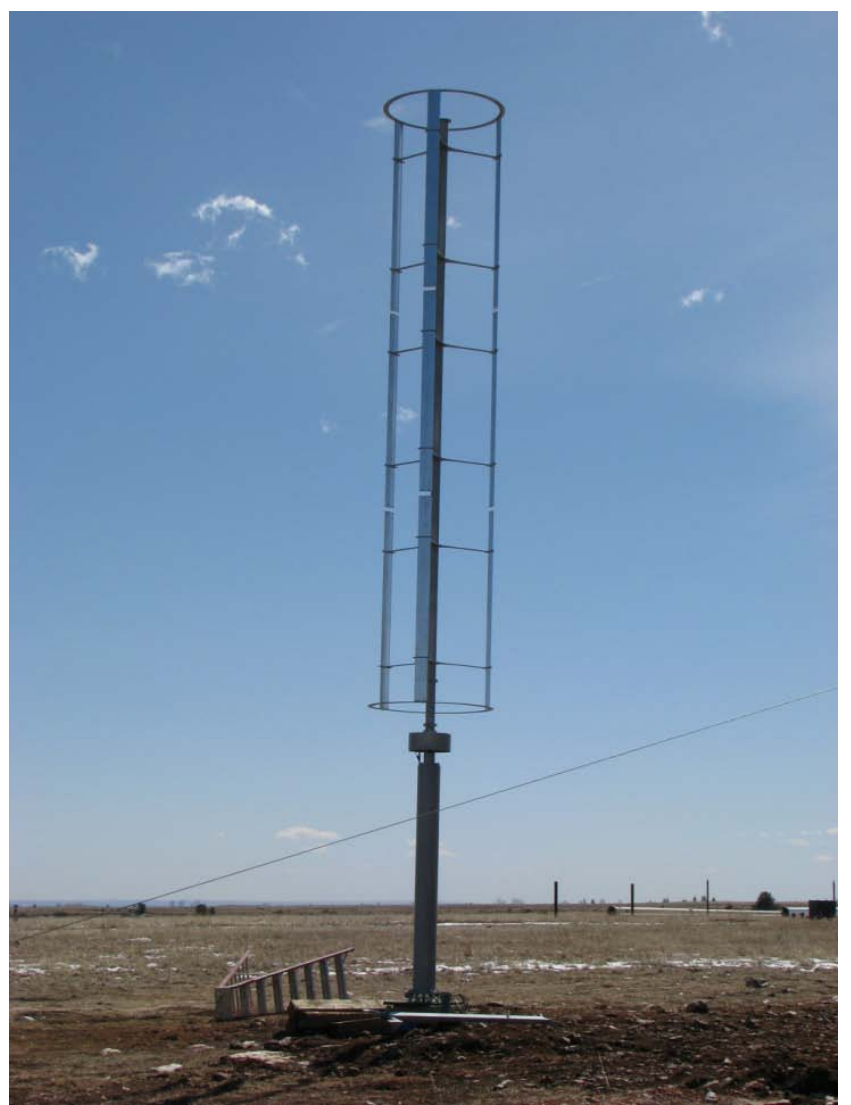

Figure 1. Windspire wind turbine at the NWTC test site

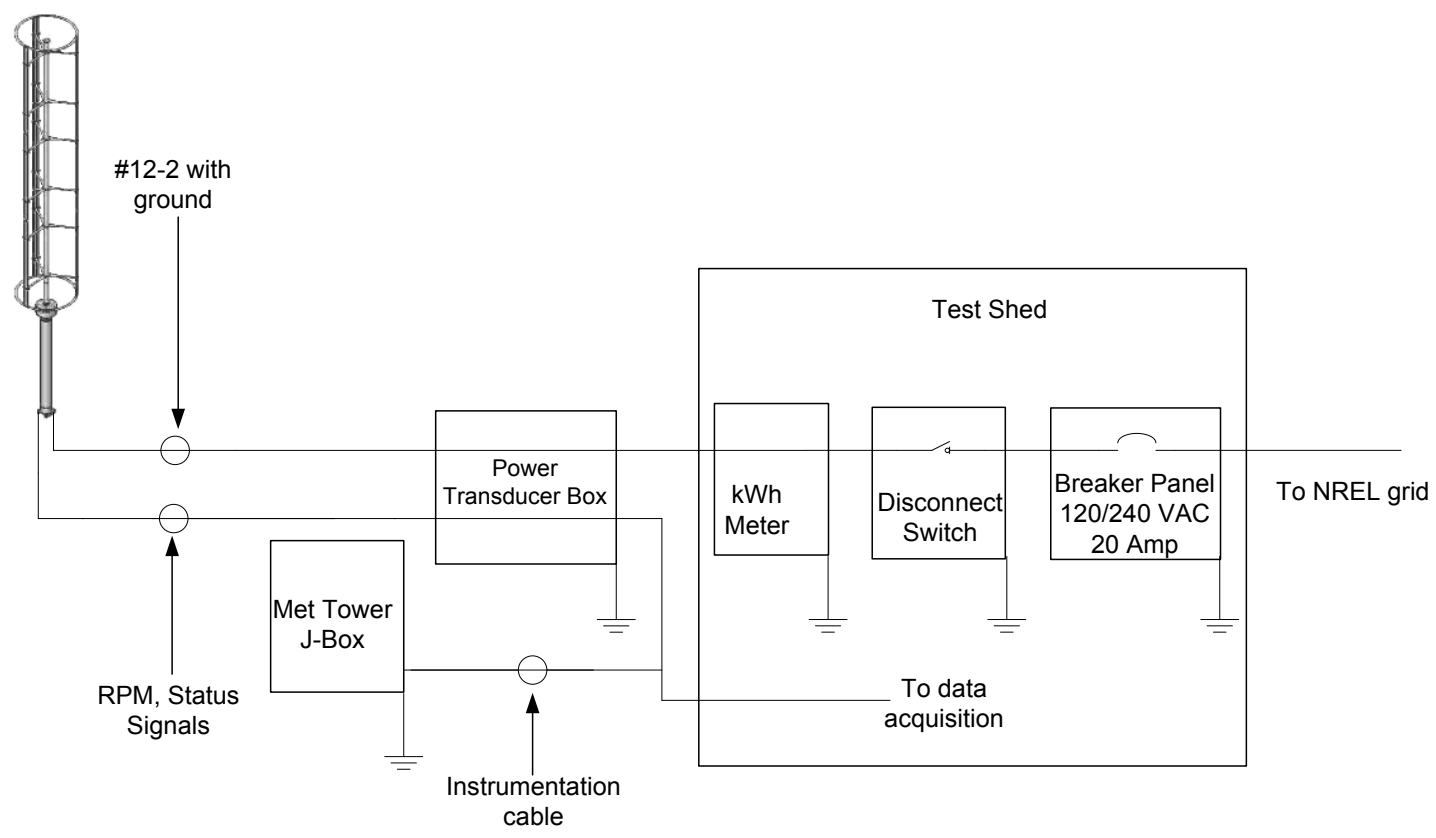

Figure 2. Electrical drawing 


\section{Instrumentation}

The following parameters were measured in this test: wind speed, electrical power, rotor speed, turbine status, and grid voltage. The rotor speed was calculated by measuring the frequency of an optically isolated signal from the turbine. The turbine does not produce a detectable rotor speed signal at lower rotor speeds. An indication of turbine status was obtained by measuring the voltage of a signal from the turbine that indicated if the turbine's brake was on. The instruments used for these measurements are listed in Table 2. The calibration sheets for the instruments used for this safety and function test are included in Appendix A.

Table 2. Equipment List for Safety and Function Test

\begin{tabular}{|c|c|c|c|}
\hline Instrument & Make, Model & $\begin{array}{l}\text { Serial } \\
\text { Number }\end{array}$ & Calibration Due Date \\
\hline $\begin{array}{l}\text { Power } \\
\text { transducer }\end{array}$ & $\begin{array}{l}\text { Second Wind, Phaser } \\
\text { 5FM-4A20 }\end{array}$ & 02061 & February 8, 2009 \\
\hline $\begin{array}{l}\text { Voltage } \\
\text { transducer }\end{array}$ & $\begin{array}{l}\text { Ohio Semitronics, VT7- } \\
\text { 010E-11 }\end{array}$ & 08010700 & Calibrated with power transducer \\
\hline $\begin{array}{l}\text { Primary } \\
\text { anemometer }\end{array}$ & Thies, First Class & 0707894 & February 27, 2009 \\
\hline $\begin{array}{l}\text { Data acquisition } \\
\text { system }\end{array}$ & $\begin{array}{l}\text { Compact DAQ w/LabView } \\
\text { cDAQ backplane } \\
\text { NI } 9229 \\
\text { NI } 9217 \\
\text { NI } 9205\end{array}$ & $\begin{array}{l}\text { 12E4D23 } \\
\text { 12B6DD2 } \\
\text { 12BD192 } \\
\text { 12E9C3E }\end{array}$ & $\begin{array}{l}\text { June } 28,2008 \\
\text { July } 6,2008 \\
\text { October } 8,2008 \\
\text { Modules post-test calibrated on } \\
\text { May 6, } 2009 \text { and found in } \\
\text { compliance }\end{array}$ \\
\hline
\end{tabular}

\section{Procedure}

Safety and function testing can involve some risk to personnel and to equipment. By incorporating appropriate controls into testing procedures, NREL endeavors to accomplish its tasks with minimal risk. This test report documents these controls in areas where they might have influenced the results obtained.

\subsection{Control and Protection System Functions}

The first part of the test procedure is assessing the control and protection system functions. The planned control and protection system tests are listed below, though not all were completed before testing was terminated. The turbine's response is observed for each major 
response category (start-up, normal shutdown, emergency shutdown) in the list below. In circumstances in which faults or other actions cause one of these major responses, NREL staff simulates the appropriate input and verifies that the control and protection system appropriately sensed the condition and provided an indication of the appropriate response. This procedure, for example, enables rotor overspeed functions to be checked without exposing the turbine to multiple potentially damaging stops. In the list below, these items are designated by the term "behavior."

1. Power control

2. Rotor-speed control

3. Start-up

a. Normal operation - wind speed greater than cut-in

b. After maintenance or fault clearance at design wind speed or greater

4. Normal shutdown under

a. Normal operation - wind speed decreasing to less than cut-in

b. Maintenance or fault conditions at design wind speed or greater

5. Emergency shutdown during operation from any operating condition including:

a. Emergency stop in wind speeds less than design wind speed;

b. Emergency stop at design wind speed or greater;

c. Behavior upon automatic shutdown from overspeed at design wind speed or greater; and

d. Behavior upon automatic shutdown from other fault at design wind speed or greater.

6. Behavior upon loss of load

a. Response to grid outage

b. Response to grid instability

\subsection{Personnel Safety Provisions}

The second part of the test procedure was to evaluate provisions for personnel safety. For the test turbine the following issues were reviewed.

1. Safety instructions

a. Safety instructions must be available for everybody working or operating at the site or in the wind turbine.

b. Safety instructions must cover installation, operation, and maintenance activities.

2. Climbing facilities must be checked for proper assembly and full function.

a. Tower climbing cable or equivalent

b. Tie-off points on outside of nacelle

3. Standing places, platforms, and floors

a. Trip hazards must be avoided or marked clearly. 
b. Platforms, floors, and walkways must be equipped with nonslip surfaces.

c. Hatches in the platforms must be lockable.

4. Electrical and grounding system

5. Emergency-stop buttons

6. Lock-out/tag-out provisions

7. Interlock on electrical cabinets

8. Presence and functioning of rotor lock and yaw lock

9. Unauthorized changing of control settings

10. Lightning protection

11. Safety signs

\subsection{Dynamic Behavior}

NREL staff observed the turbine at a range of operating wind speeds to note the dynamic behavior of the turbine, including (but not limited to) vibration, and noise.

\section{Results}

\subsection{Control and Protection System Functions}

NREL limited testing to investigation of single-fault failures and has not investigated failures of "safe life" components. ${ }^{1}$ If a second fault occurs during a critical event, unsafe results could occur. Neither NREL nor the IEC turbine-design requirements make judgments on whether such failures are likely or whether additional features in the control and protection system are needed to protect against such consequences.

\section{Power Control}

Figure 3 shows the 1-minute mean power data and 1-second maximum power data for the inverter configured for standard power production. For the data collected, both the mean and maximum power values appear to begin leveling off at wind speeds greater than $14 \mathrm{~m} / \mathrm{s}$. However, there are not enough data points at these wind speeds to conclude that the turbine exhibits power control.

\section{Yaw Control}

This item is not applicable as the test article is a vertical axis turbine.

\footnotetext{
${ }^{1}$ The IEC turbine design standard, IEC 61400-1, defines "safe life" as those components for which the designer has "prescribed a service life with a declared probability of failure." These typically are components that transmit wind loads to the ground, such as blades, hubs, low-speed shafts, main bearings, main frames, yaw bearings, towers, and foundations. Failure of any of these components could lead to a catastrophic failure of the turbine; therefore each component should be designed with an appropriate safety factor. NREL has not evaluated these design characteristics and makes no judgment on whether appropriate safety factors have been used.
} 


\section{Rotor-Speed Control}

Rotor-speed measurements over the test period indicate that the turbine system exhibits control over rotor speed in response to winds below about $18 \mathrm{~m} / \mathrm{s}$. Figure 4 shows both 1minute average and 1-second maximum rotor speed for the inverter configured for standard power production. The maxima level off and hold at about $390 \mathrm{rpm}$. The manufacturer's rated rotor speed is $380 \mathrm{rpm}$ and a rotor overspeed occurs at $430 \mathrm{rpm}$. The data shows the rotor speed was held at less than $430 \mathrm{rpm}$.

\section{Start-Up}

Normal Operation-Wind Speed Greater Than Cut-In (4 m/s). This event was captured in June 2008 on the inverter configured for optimized power production. As shown in Figure 5, the wind speeds were slightly greater than the cut-in wind speed when the turbine started. The rotor speed gradually increased as the wind speeds remained constant at approximately $4 \mathrm{~m} / \mathrm{s}$. The turbine began producing power at a wind speed of about $4 \mathrm{~m} / \mathrm{s}$ and a rotor speed of about 180 RPM.

After Maintenance or Fault Clearance at Design Wind Speed $(8.4 \mathrm{~m} / \mathrm{s})$ or Greater. This event occurred in June 2008 on the inverter configured for optimized power production. The turbine was stopped through the communication software for maintenance. After the turbine was enabled through the communication software, it started in winds between 9 and $13 \mathrm{~m} / \mathrm{s}$ and began producing power. Figure 6 shows a time series of the events.

\section{Normal Shutdown}

Normal Operation-Wind Speed Decreasing to Less Than Cut-ln $(4 \mathrm{~m} / \mathrm{s})$. This event was recorded in September 2008 on the inverter configured for optimized power production. When the wind speed decreases to less than cut-in the turbine stops producing power and then free wheels. A time series of the event is shown in Figure 7.

Maintenance or Fault Conditions at Design Wind Speed $(8.4 \mathrm{~m} / \mathrm{s})$ or Greater. This event was recorded in June 2008 on the inverter configured for optimized power production. The turbine was stopped through the communication software for maintenance. The wind speed was between $8.4 \mathrm{~m} / \mathrm{s}$ and $9.0 \mathrm{~m} / \mathrm{s}$ at the time the turbine was stopped. The brake was applied and both the detectable rotor speed and power dropped to zero within 2 seconds. Figure 8 shows a time series of the event.

\section{Emergency Shutdown from Any Operating Condition During Operation} Emergency Stop in Wind Speeds Less Than Design Wind Speed $(8.4 \mathrm{~m} / \mathrm{s})$. The owner's manual indicates that the owner should disconnect power to the turbine to stop it in high winds. Thus, the emergency shutdown capability was tested by opening the dedicated disconnect switch that NREL installed. This event was recorded in June 2008 on the inverter configured for optimized power production. The wind speeds were between $4 \mathrm{~m} / \mathrm{s}$ and $6 \mathrm{~m} / \mathrm{s}$ when the disconnect switch for the turbine was opened. The brake stopped the wind turbine within 2 seconds. Figure 9 shows a time series of the event. 
Emergency Stop at Design Wind Speed $(8.4 \mathrm{~m} / \mathrm{s})$ or Greater. This event was recorded in October 2008 on the inverter configured for standard power production in a data file containing one minute averages. The wind speed was between $10 \mathrm{~m} / \mathrm{s}$ and $19 \mathrm{~m} / \mathrm{s}$ during the one minute period when the disconnect switch was opened to shut the turbine down at the request of the manufacturer for high winds. Figure 10 shows the one minute time series of the event.

Behavior Upon Automatic Shutdown from Overspeed at Design Wind Speed or Greater. No data was collected for this category before testing was terminated.

Behavior Upon Automatic Shutdown from other fault at Design Wind Speed $(8.4 \mathrm{~m} / \mathrm{s})$ or Greater. No data was collected for this category before testing was terminated.

\section{Behavior Upon Loss of Load}

Response to Grid Outage. This event was observed in June 2008 on the inverter configured for optimized power production. The wind speeds were between $4 \mathrm{~m} / \mathrm{s}$ and $6 \mathrm{~m} / \mathrm{s}$ when the disconnect switch for the turbine was opened. The brake stopped the wind turbine within 2 seconds. After the switch was opened, the turbine voltage increased to $150 \mathrm{~V}$ before dropping to $0 \mathrm{~V}$. Figure 9 shows a time series of the event.

Response to Grid Instability. No data was collected for this category before testing was terminated.

\subsection{Personnel Safety Provisions Safety Instructions}

The turbine came with an owner's manual detailing the installation, operation, and maintenance procedures. NREL staff checked the manual to determine whether the safety instructions addressed requirements in accordance with the IEC small turbine design standard. NREL staff found the following.

Disengage the load and/or energy sources: The manual indicates that the owner should disconnect power to the turbine if high winds are anticipated, if damage is suspected, or before servicing the turbine. The turbine was not supplied with a means of disconnecting power, though the one line diagram in the manual shows the turbine connected to a disconnect switch. NREL staff installed a dedicated disconnect switch in the data shed as a means to disconnect power to the turbine.

Stop and secure the rotor: The manual states that the rotor should be secured if damage is suspected or if the inverter is disconnected from the generator. The manual does not provide specific instructions on securing the rotor.

Stop and secure the yaw mechanism: This item is not applicable as the test article is a vertical axis turbine. 
Climb tower: The turbine is not equipped with a ladder or other means of climbing the tower. The owner's manual indicates that the turbine should be lowered to perform maintenance such as replacing the blades or the bearings.

\section{Climbing}

The turbine tower was not intended for climbing. To service or inspect the turbine, NREL staff used a ladder, an aerial lift, or lowered the turbine as suggested in the owner's manual.

\section{Standing Places, Platforms, and Floors}

The turbine does not have any standing places, platforms, or floors.

\section{Electrical and Grounding System}

The electrical system consists of wiring from the turbine to a disconnect switch and then to a dedicated circuit breaker. The grounding system consists of a pole ground connected to the tower base. The details of the electrical and grounding system are shown in a wiring diagram in the owner's manual.

\section{Emergency-Stop Button}

The turbine was not supplied with an emergency-stop button. NREL staff stopped the turbine by opening the disconnect switch. Alternatively the turbine can be stopped through entering a command in the communications software.

\section{Lock-Out/Tag-Out Provisions}

NREL provided a lockable switch between the grid and the turbine. The manufacturer shows installation of a disconnect switch in the owner's manual, though they do not specifically require a lockable switch. Limited procedures for de-energizing the turbine system using this disconnect switch are in the owner's manual.

\section{Interlock on Electrical Cabinets}

The turbine was not supplied with an electrical cabinet.

\section{Safety Signs}

The turbine was not provided with any safety signs, safety notices are not a part of the turbine's bill of materials. NREL personnel labeled the electrical panels, and disconnects, indicating the voltage levels of each.

\section{Presence and Functioning of Rotor Lock and Yaw Lock}

The turbine stops the rotor with a redundant electronic brake which can be activated through the communication software, or a disconnect switch. As indicated in the manual, with the electronic brake applied the turbine maintains a low rotor speed in high winds. There are no instructions for locking the rotor to prevent the low rotor speed. A yaw lock is not applicable for the Windspire as it is a vertical axis turbine.

\section{Unauthorized Changing of Control Settings}

The controller functions are performed by the turbine's inverter. The inverter set points can be changed by communicating with the inverter wirelessly through a modem. The access mode in the communication software that NREL was provided with has the ability to be password 
protected. The control settings may be changed by the turbine owner with the communication software, password, and necessary code provided by Mariah Power.

\section{Lighting Protection}

As indicated in the owner's manual, the turbine "has a built-in lightning arrestor in the inverter". During the test period no direct or nearby lightning strikes were observed.

\subsection{Dynamic Behavior}

Turbine operation was observed by NREL personnel for at least 5 minutes at wind speeds of approximately $5 \mathrm{~m} / \mathrm{s}, 10 \mathrm{~m} / \mathrm{s}, 15 \mathrm{~m} / \mathrm{s}$, and $20 \mathrm{~m} / \mathrm{s}$ for a total observation period of at least 1 hour. The following are a few dynamic behavior observations that were made during the test period:

July 21,2008

This event was observed for the inverter configured for optimized power production. The leading edge tape on the turbine is beginning to separate from the blade. There is an unknown vibration and noise that seems to be coming from the foundation. The wind speeds were between 4 and $7 \mathrm{~m} / \mathrm{s}$ during this observation.

October 29, 2008

This event was observed on the inverter configured for standard power production. The turbine was exhibiting unsteady behavior periodically. There was a noise that seemed to come from the tower approximately three times per revolution. The washers at the foundation base were loose and the bolts and nuts on the foundation have shifted. The wind speeds were between 4 and $9 \mathrm{~m} / \mathrm{s}$ during this observation. 


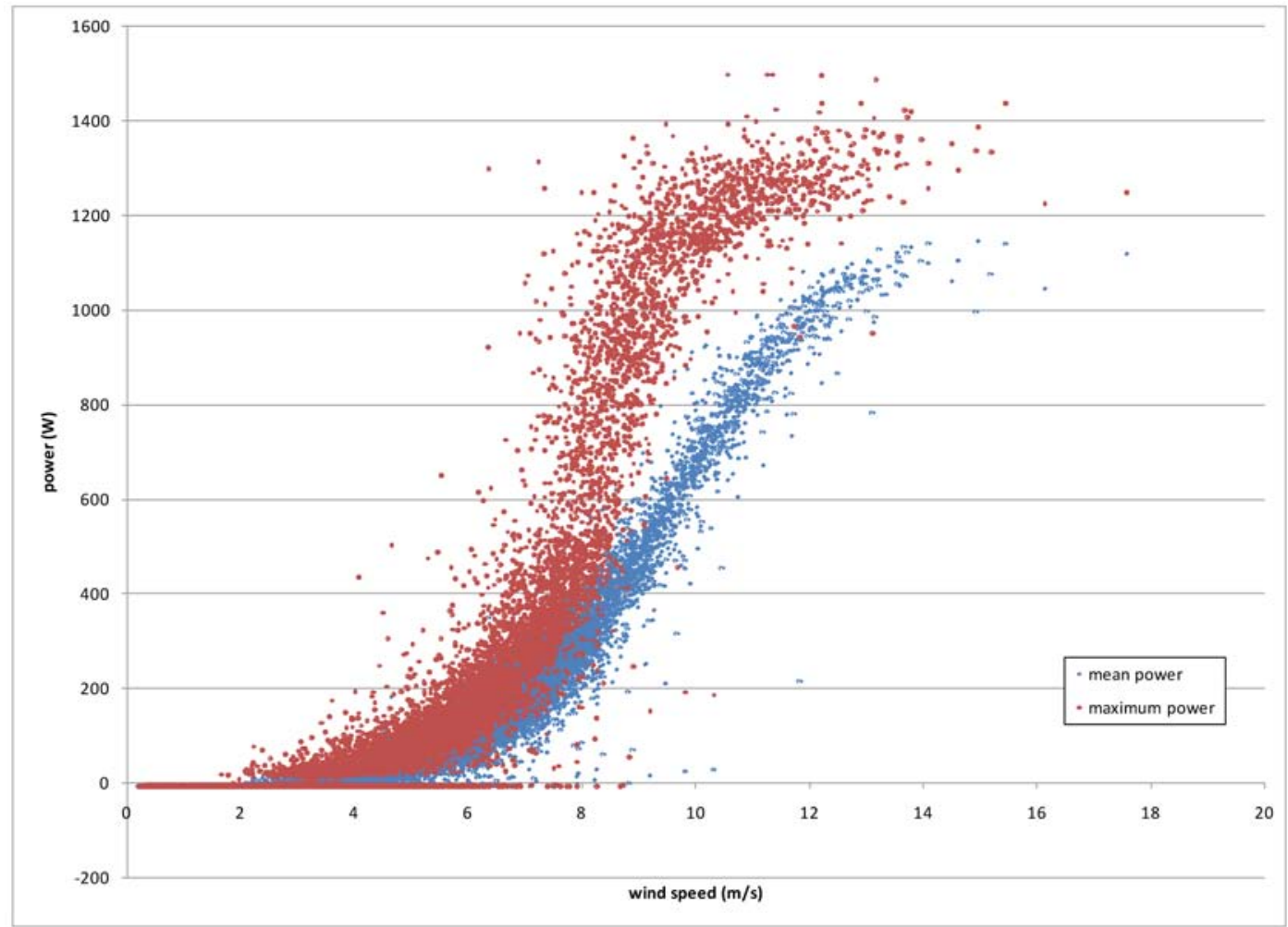

Figure 3. Power response to wind speed

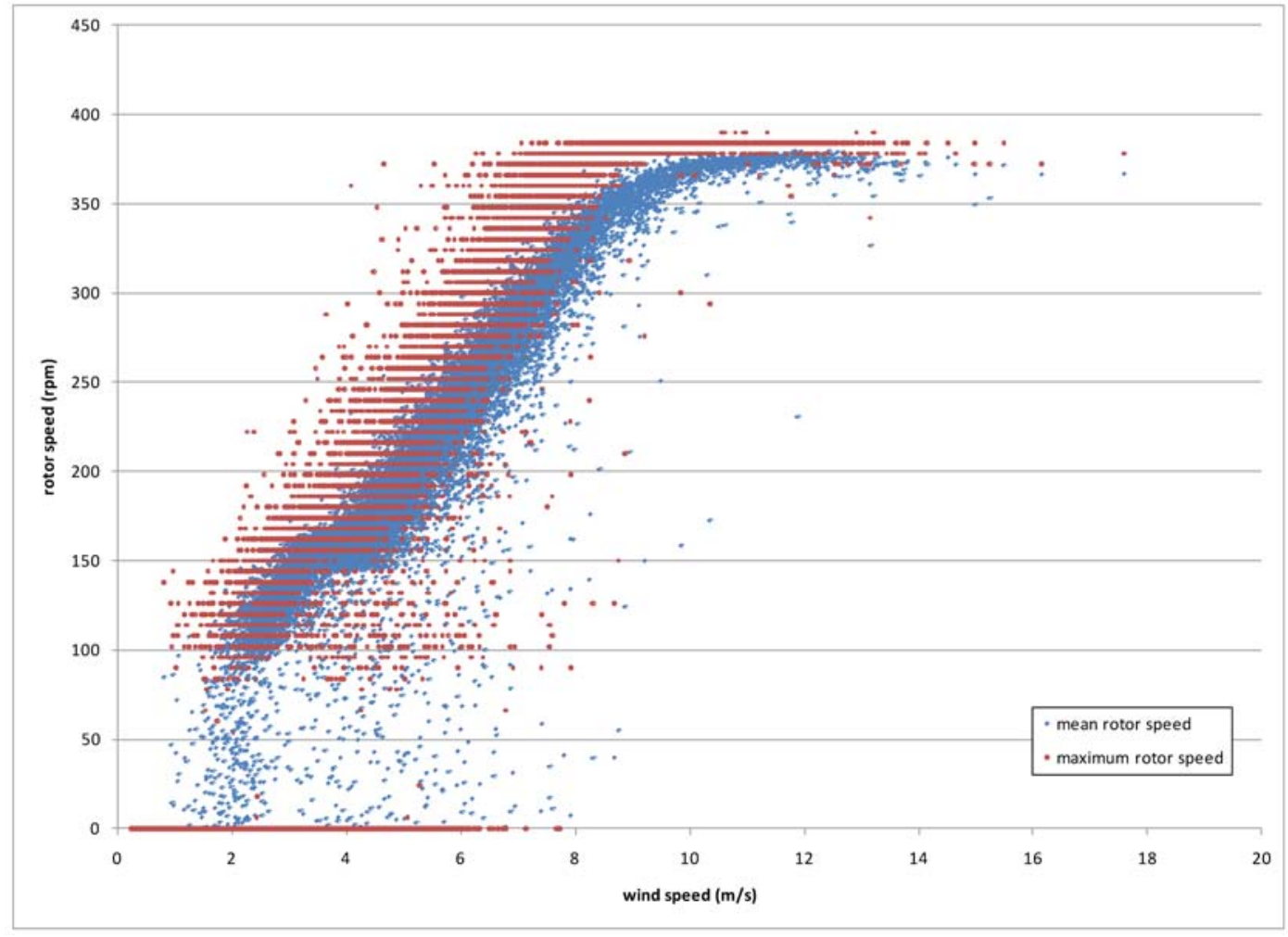

Figure 4. Rotor-speed response to wind speed 


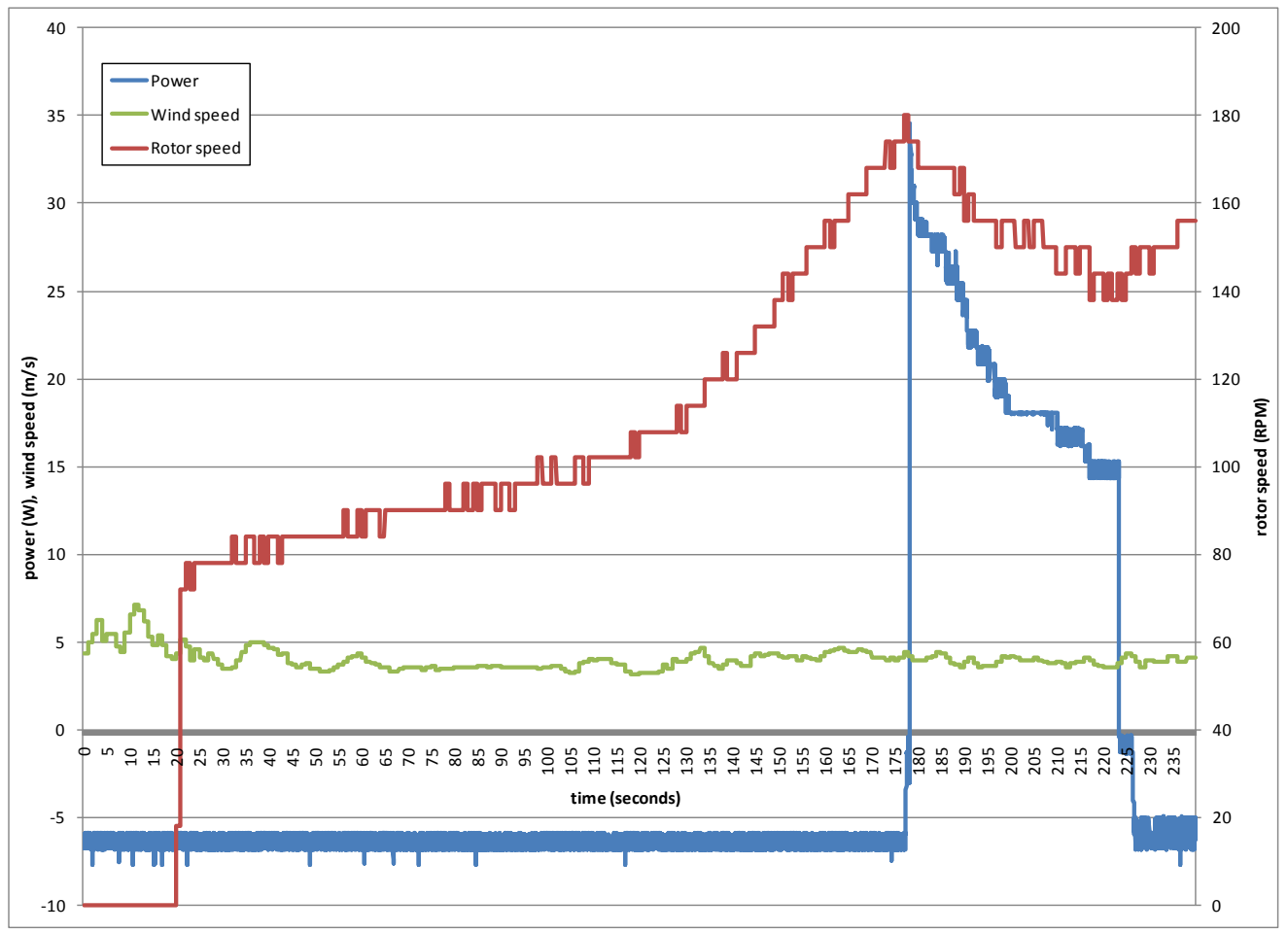

Figure 5. Normal start-up, wind speeds greater than cut-in

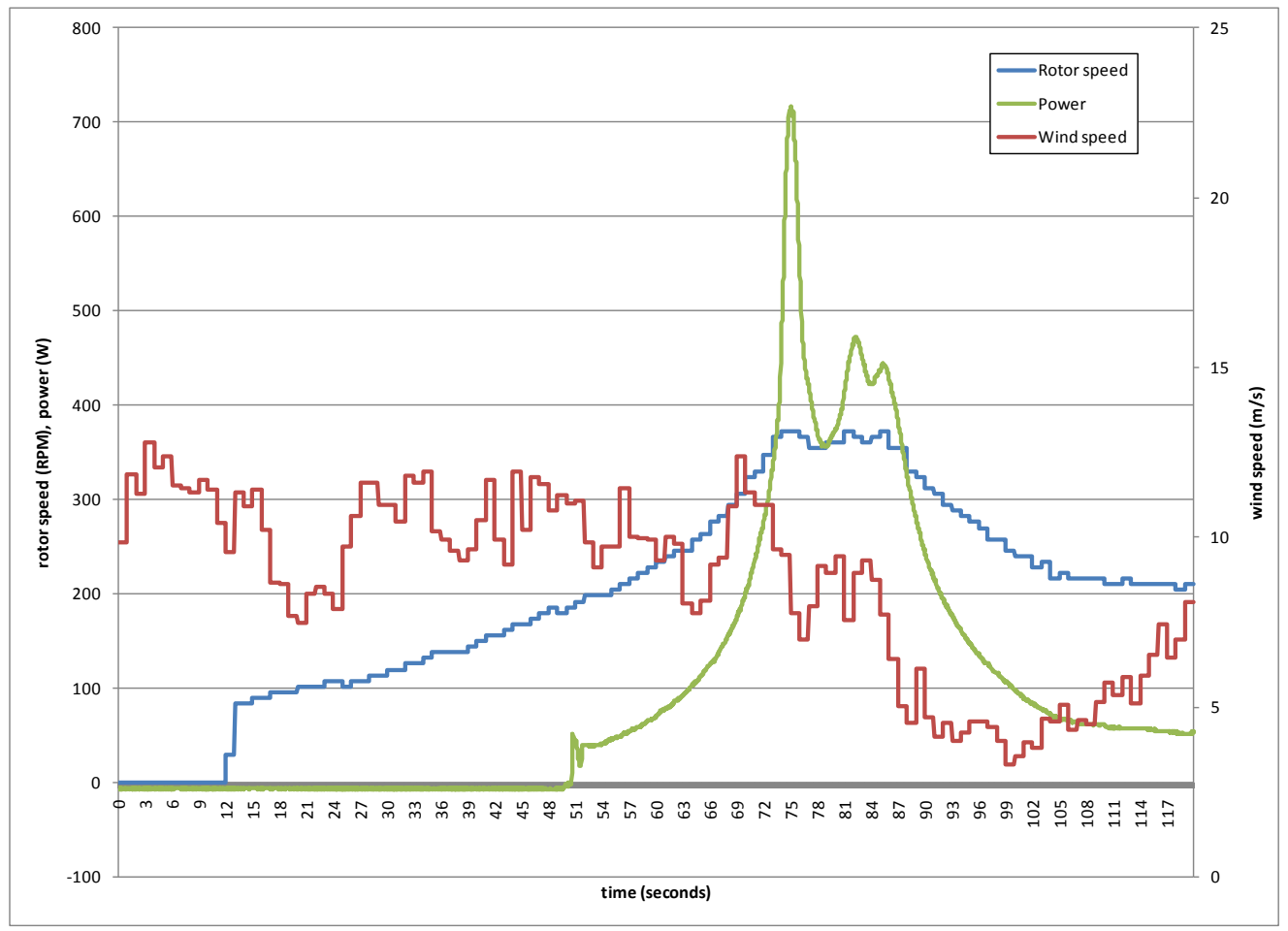

Figure 6. Normal start-up after maintenance 


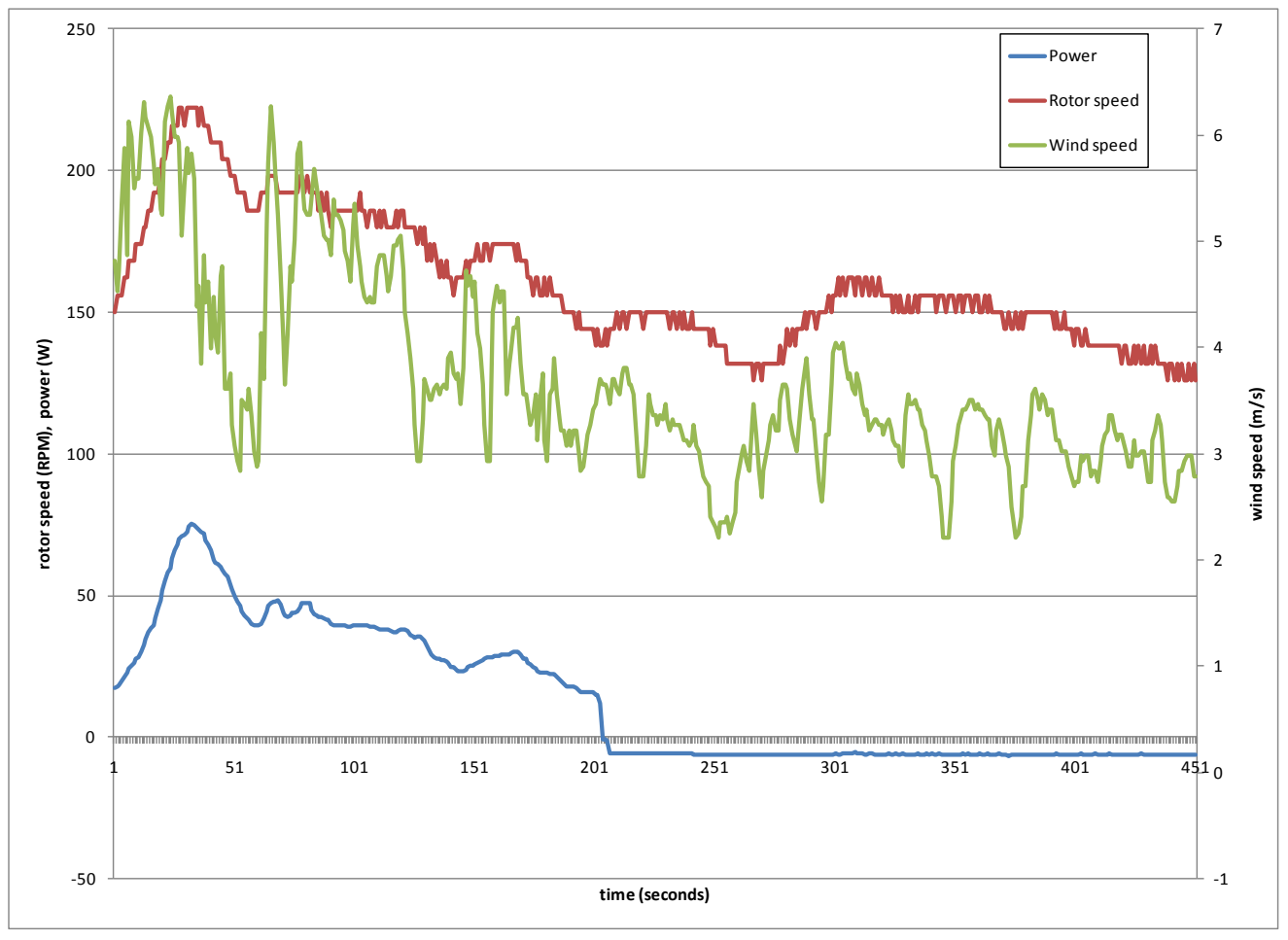

Figure 7. Normal shut down, winds decreasing below cut in

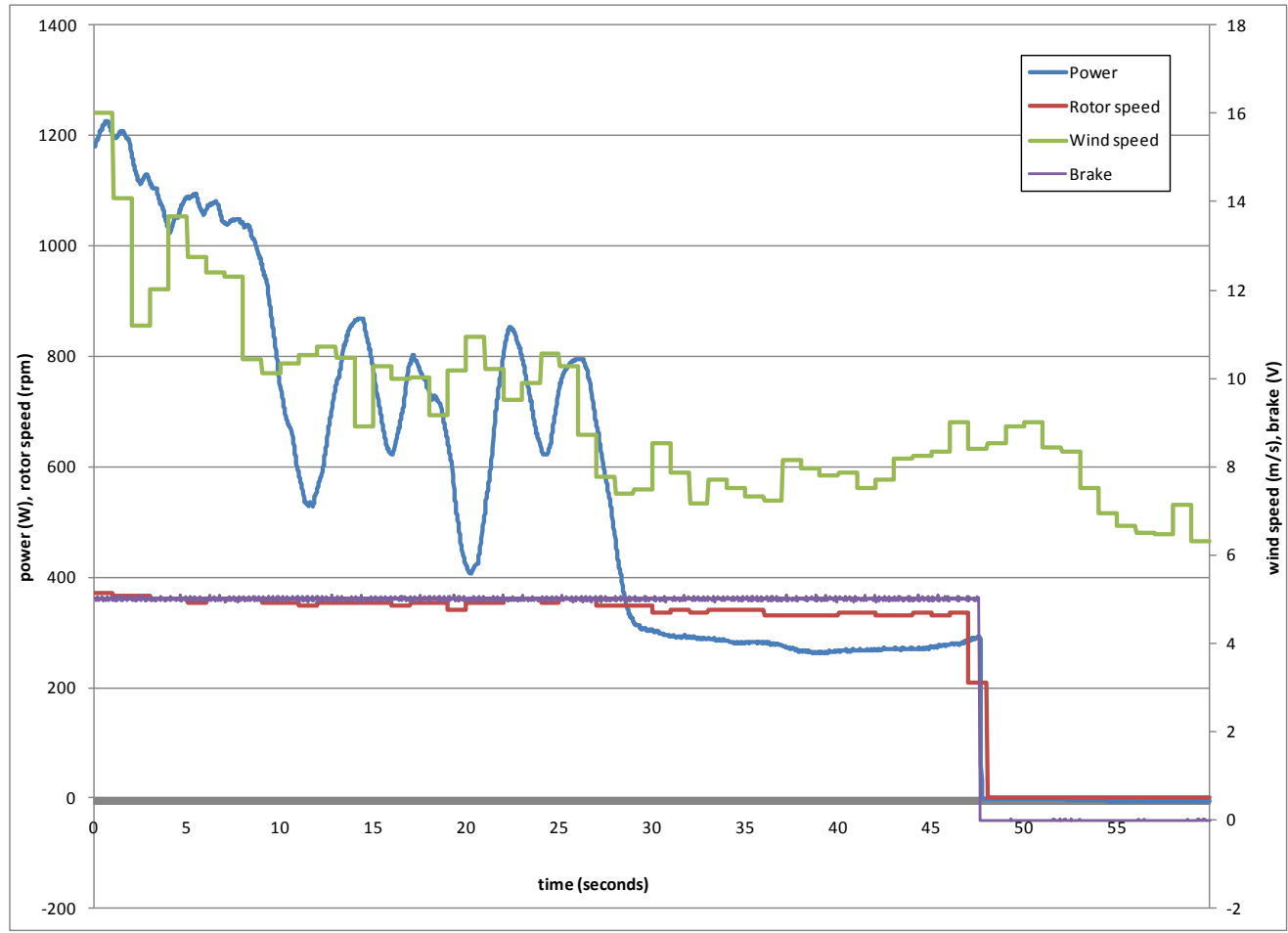

Figure 8. Normal shut down, maintenance at design wind speed or greater 


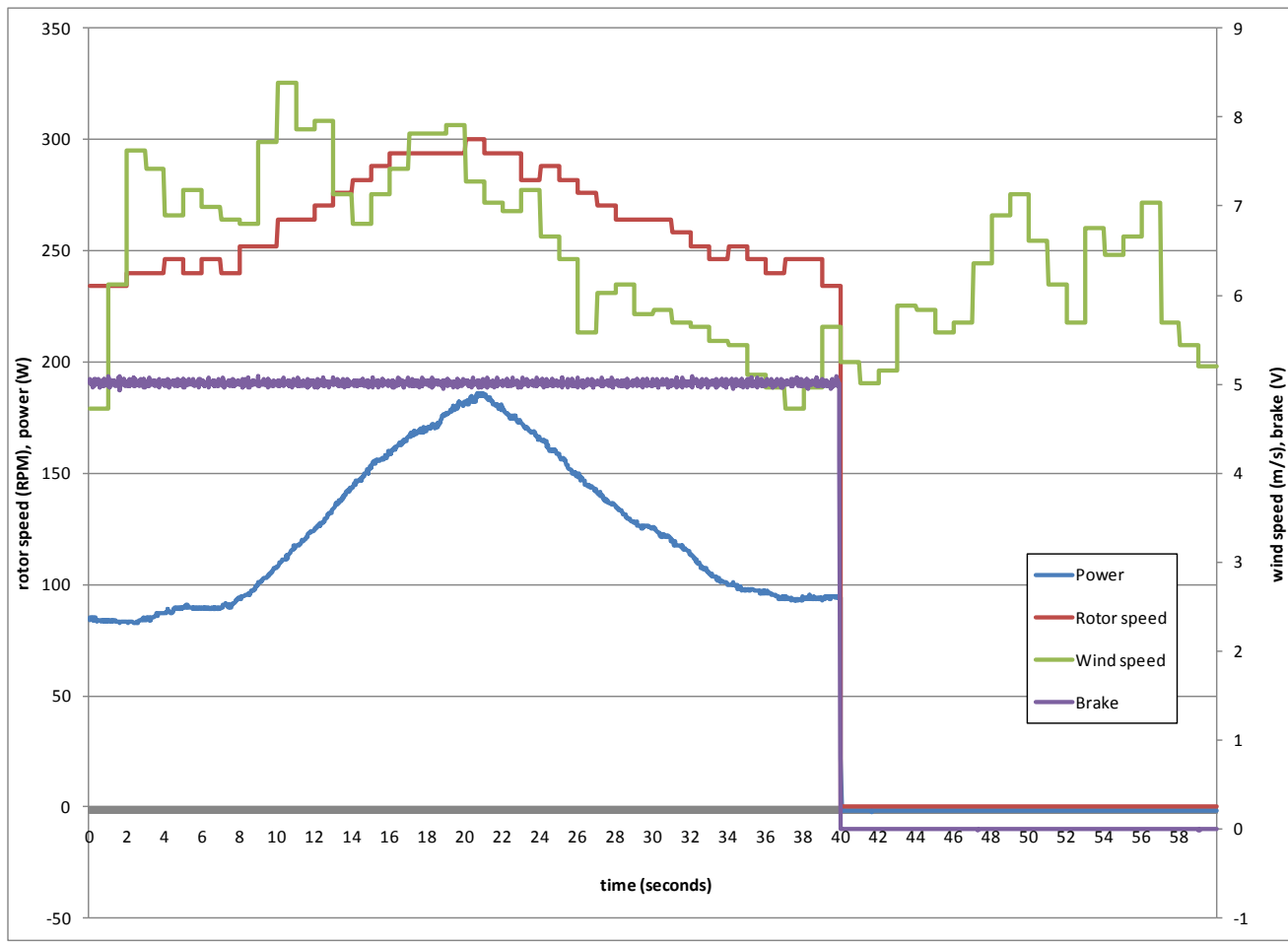

Figure 9. Emergency stop at wind speeds less than the design wind speed

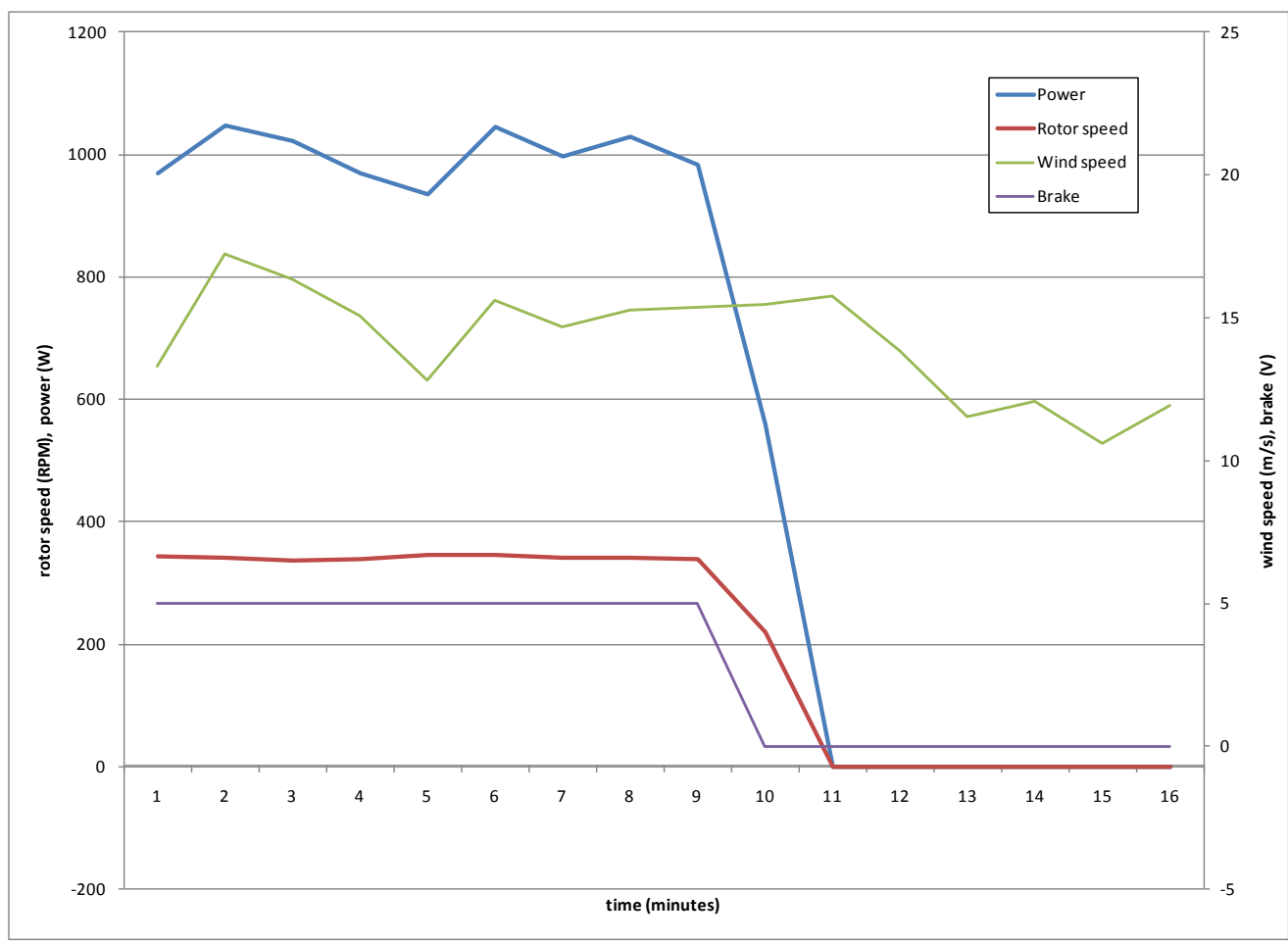

Figure 10. Emergency stop at design wind speed or greater 


\section{Deviations and Exceptions}

\subsection{Deviations from the Standard}

Testing was terminated on the Windspire before testing of all of the critical functions listed in the IEC standard could be completed. The overspeed protection at design wind speed or above function that is listed in the IEC standard as a critical function was not tested.

\subsection{Exceptions to the NWTC Quality Assurance System}

The data acquisition modules were used beyond the calibration due date. The modules were post-test calibrated and found to be in compliance within the specifications. Appendix A includes the post-test calibration sheets. 


\section{Appendix A. Instrument Calibration Sheets}

Branch \#: 5000

NREL METROLOGY LABORATORY

Test Report

Test Instrument: phaser power Transducer \& $1-C r$

DOE \# : $02825 \mathrm{C}$

Model \#

: Phaser-5-4A 20

$S / N: 02061$

Calibration Date: 02/08/2008

Due Date: $02 / 08 / 2010$

A. Set-Up for Total Real power Calibration:

A.1. Voltage is applied to phases $A \& N=100 \mathrm{~V}$ (3) $60 \mathrm{~Hz}$

A.2. Current is applied to $n=10$-TURNS through the current transformer

that is connected to phases $A$.

A.3. Analog Output- 1 is measured across precision resistor $=250 \Omega$

A.4. Phaser Full scale setting $=-1.5 \mathrm{KW}$ to $1.5 \mathrm{KW}$.

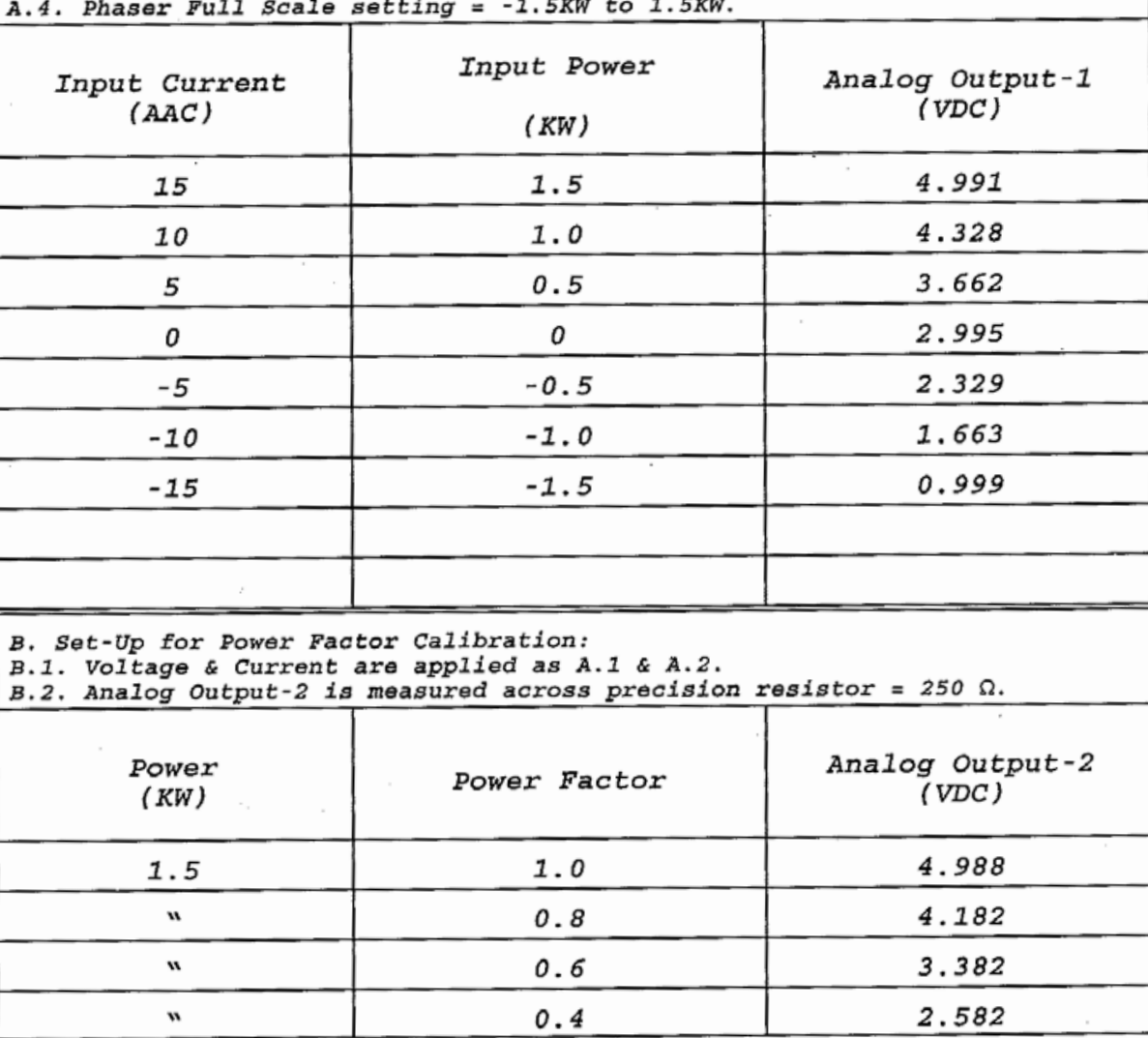

Page 1 of 2

Figure A.1. Power transducer calibration sheet 


\section{DEUTSCHER KALIBRIERDIENST DKD}

Kalibrierlaboratorium für Strömungsgeschwindigkeit von Luft Calibration laboratory for velocity of air flow

Akkreditiert durch die / accredited by the

Akkreditierungsstelle des DKD bei der

PHYSIKALISCH-TECHNISCHEN BUNDESANSTALT (PTB)

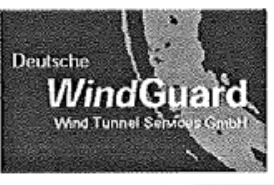
Deutsche WindGuard
Wind Tunnel Services $\mathrm{GmbH}$
Varel

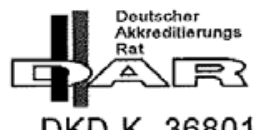

DKD-K- 36801

Kalibrierschein

Calibration Certificate

$\begin{array}{ll}\begin{array}{l}\text { Gegenstand } \\ \text { Object }\end{array} & \text { Cup Anemometer } \\ \begin{array}{l}\text { Hersteller } \\ \text { Manufacturer }\end{array} & \begin{array}{c}\text { Thies Clima } \\ \text { D-37083 Gottingen }\end{array} \\ \begin{array}{l}\text { Typ } \\ \text { Type }\end{array} & 4.3350 .00 .000 \\ \begin{array}{l}\text { Fabrikat/Serien-Nr. } \\ \text { Serial number }\end{array} & \text { Body: } 0707894 \\ \begin{array}{l}\text { Auftraggeber } \\ \text { Customer }\end{array} & \text { Cup: } 0707894 \\ & \text { Thies Clima } \\ \begin{array}{l}\text { Auftragsnummer } \\ \text { Order No. }\end{array} & \text { D-37083 Göttingen } \\ \begin{array}{l}\text { Anzahl der Seiten des Kalibrierscheines } \\ \text { Number of pages of the certificate }\end{array} \\ \begin{array}{l}\text { Datum der Kalibrierung } \\ \text { Date of calibration }\end{array} & \text { 24.07.2007 }\end{array}$

\begin{tabular}{c|c|}
\hline \multirow{4}{*}{\begin{tabular}{c|} 
Kalibrierzeichen \\
Calibration label
\end{tabular}} & \\
\cline { 2 - 2 } & DKD-K- \\
\cline { 2 - 2 } & $\mathbf{0 7 \_ 2 4 0 7}$ \\
\hline
\end{tabular}

Dieser Kalibrierschein dokumentiert die Rückführung auf nationale Normale zur Darstellung der Einheiten in Übereinstimmung mit dem Internationalen Einheitensystem (SI).

Der DKD ist Unterzeichner der multi- lateralen Öbereinkommen der European co-operation for Accreditation (EA) und der Internationa Laboratory Accreditation Cooperation (ILAC) zur gegenseitigen Anerkennung der Kalibrierscheine.

Für die Einhaltung einer angemessenen Frist zur Wiederholung der Kalibrierung ist der Benutzer verantwortlich.

This calibration certificate documents the traceability to national standards, which realize the units of measurement according to the Intemational System of Units (SI).

The $D K D$ is signatory to the multilateral agreements of the European co-operation for Accreditation (EA) and of the Intemational Laboratory Accreditation Cooperation (ILAC) for the mutual recognition of calibration certificates.

The user is obliged to have the object recalibrated at appropriate intervals.

Dieser Kalibrierschein darf nur vollständig und unverändert weiterverbreitet werden. Auszüge oder Ånderungen bedürfen der Genehmigung sowohl der Akkreditierungsstelle des DKD als auch des ausstellenden Kalibrierlaboratoriums. Kalibrierscheine ohne Unterschrift und Stempel haben keine Gültigkeit.

This calibration certificate may not be reproduced other than in full except with the permission of both the Accreditation Body of the DKD and the issuing laboratory. Calibration certificates without signature and seal are not valid.

Stempel
Deutsche WindGuard Wind Tunnel Services GmbH
Oldenburger Str. 65
26316 Varel ; Tel. ++49 (0)4451 95150

Figure A.2. Primary anemometer calibration sheet 
Board Information:

Serial Number: 12B6DD2

NI Part Number: 192580D-02

Description: NI 9229

Calibration Date: 28-JUN-07

Recommended Calibration Due Date: 28-JUN-08*

Ambient Temperature: $24^{\circ} \mathrm{C}$

Relative Humidity: $39 \%$
Certificate Information:

Certificate Number: 756395

Date Printed: 02-JUN-09

National Instruments certifies that at the time of manufacture, the above product was calibrated in accordance with applicable National Instruments procedures. These procedures are in compliance with relevant clauses of ISO 9001 and are designed to assure that the product listed above meets or exceeds National Instruments specifications.

National Instruments further certifies that the measurements standards and instruments used during the calibration of this product are traceable to National and/or International Standards administered by NIST or Euromet members or are derived from accepted values of natural physical constants.

The environment in which this product was calibrated is maintained within the operating specifications of the instrument and the standards.

The information shown on this certificate applies only to the instrument identified above and the certificate may not be reproduced, except in full, without prior written consent by National Instruments.

For questions or comments, please contact National Instruments Technical Support.

NI Hungary Software és

Hardware Gyártó Kft.

4031 Debrecen, Határ út

$1 / A$.

HUNGARY
Signed,

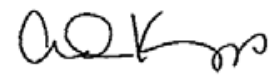

Andrew Krupp

Vice President, Quality and Continuous Improvement

* Recommended calibration due date is based on a combination of calibration interval and, when applicable, calibration shelf life. This date may vary depending on your application requirements.

Figure A.3. National Instruments 9229 data-acquisition module calibration sheet I 
Board Information:

Serial Number: 12BD192

NI Part Number: 192547D-01

Description: NI 9217

Calibration Date: 06-JUL-07

Recommended Calibration Due Date: 06-JUL-08*

Ambient Temperature: $23^{\circ} \mathrm{C}$

Relative Humidity: $43 \%$
Certificate Information:

Certificate Number: 762337

Date Printed: 02-JUN-09

National Instruments certifies that at the time of manufacture, the above product was calibrated in accordance with applicable National Instruments procedures. These procedures are in compliance with relevant clauses of ISO 9001 and are designed to assure that the product listed above meets or exceeds National Instruments specifications.

National Instruments further certifies that the measurements standards and instruments used during the calibration of this product are traceable to National and/or International Standards administered by NIST or Euromet members or are derived from accepted values of natural physical constants.

The environment in which this product was calibrated is maintained within the operating specifications of the instrument and the standards.

The information shown on this certificate applies only to the instrument identified above and the certificate may not be reproduced, except in full, without prior written consent by National Instruments.

For questions or comments, please contact National Instruments Technical Support.

NI Hungary Software és Hardware Gyártó Kft. 4031 Debrecen, Határ út $1 / A$.

HUNGARY
Signed,

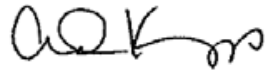

Andrew Krupp

Vice President, Quality and Continuous Improvement

* Recommended calibration due date is based on a combination of calibration interval and, when applicable, calibration shelf life. This date may vary depending on your application requirements.

Figure A.4. National Instruments 9217 data-acquisition module calibration sheet I 
Board Information:

Serial Number: 12E9C3E

NI Part Number: 193299F-01

Description: NI-9205

Calibration Date: 08-OCT-07

Recommended Calibration Due Date: 08-OCT-08*

Ambient Temperature: $22^{\circ} \mathrm{C}$

Relative Humidity: $39 \%$
Certificate Information:

Certificate Number: 834976

Date Printed: 02-JUN-09

National Instruments certifies that at the time of manufacture, the above product was calibrated in accordance with applicable National Instruments procedures. These procedures are in compliance with relevant clauses of ISO 9001 and are designed to assure that the product listed above meets or exceeds National Instruments specifications.

National Instruments further certifies that the measurements standards and instruments used during the calibration of this product are traceable to National and/or International Standards administered by NIST or Euromet members or are derived from accepted values of natural physical constants.

The environment in which this product was calibrated is maintained within the operating specifications of the instrument and the standards.

The information shown on this certificate applies only to the instrument identified above and the certificate may not be reproduced, except in full, without prior written consent by National Instruments.

For questions or comments, please contact National Instruments Technical Support.

NI Hungary Software és Hardware Gyártó Kft.

4031 Debrecen, Határ út

$1 / A$.

HUNGARY
Signed,

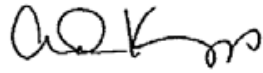

Andrew Krupp

Vice President, Quality and Continuous Improvement

* Recommended calibration due date is based on a combination of calibration interval and, when applicable, calibration shelf life. This date may vary depending on your application requirements.

Figure A.5. National Instruments 9205 data-acquisition module calibration sheet I 
Davis|Calibration

Company ID: 229037

NATIONAL INSTRUMENTS

11500 N. MOPAC EXPWY

ATTN. RMA DEPT.

AUSTIN, TX 78759

Instrument ID: $12 \mathrm{~B} 6 \mathrm{DD} 2$

Manufacturer. NATIONAL INSTRUMENTS

Description: 4-CHANNEL, $\pm 60 \mathrm{~V}, 24-\mathrm{BIT}$ SIMULTANEOUS ANALOG INPUT

Instrument Identification

\section{Certificate of Calibration}

3214335

Cortificate Page 1 of 1

\author{
PO Number: 337683
}

Accuracy: Mfr Specifications

Model Number: NI 9229

Serial Number: 12B6DD2

Certificate Information

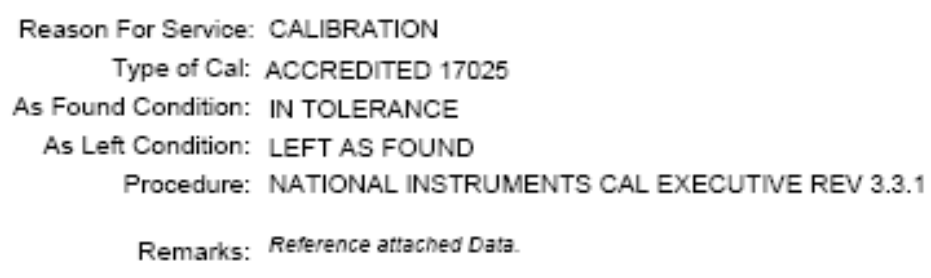

Remarks: Reference attached Data.

Approved By: VICTOR PENA

Service Representative

Calibration Standards

$\frac{\text { NIST Traceable\# }}{3143038} \frac{\text { Inst. ID\# }}{15-0271} \quad \frac{\text { Description }}{\text { MULTIFUNCTION CALIBRATOR }} \quad \frac{\text { Model }}{5700 \mathrm{~A}} \quad \frac{\text { Cal Date }}{15 \text { Apr2009 }} \frac{\text { Date Due }}{14 J \text { Jul2009 }}$

Davis Calibration - 2324 Ridgepoint Drive, Suite D - Austin, TX 78754 - Phone: 800-365-0147 • Fax: 512-926-8450

Figure A.6. National Instruments 9229 data-acquisition module calibration sheet II 
Davis Calibration

Company ID: 229037

NATIONAL INSTRUMENTS

11500 N. MOPAC EXPWY

ATTN. RMA DEPT.

AUSTIN, TX 78759

Instrument ID: 12BD192

Manufacturer: NATIONAL INSTRUMENTS

Description: 4-CH 100 OHM 24-BIT RTD ANALOG INPUT

Accuracy: Mfr. Specifications

\section{Certificate of Calibration}

3214168

Certificate Page 1 of 1

Instrument Identification

PO Number: 337683

Model Number: NI 9217

Serial Number: 12BD192

Certificate Information

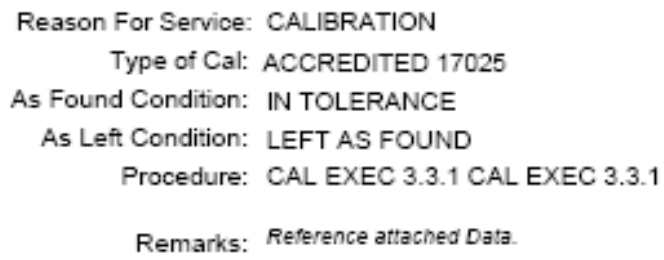

Technician: WAYNE GETCHELL Cal Date 06May2009 Cal Due Date: 06May2010 Interval: 12 MONTHS

Temperature: $23.0 \mathrm{C}$ Humidity: $46.0 \%$

Approved By: VICTOR PENA

Service Representa:ive

\section{Calibration Standards}

\begin{tabular}{|c|c|c|c|c|c|}
\hline NIST Traceable\# & Inst. ID\# & Description & Model & Cal Date & Date Due \\
\hline 3078982 & $15 \cdot 0011$ & DECADE RESISTOR & DB52 & $24 \mathrm{Mar} 2009$ & $24 \mathrm{Mar} 2010$ \\
\hline 3004176 & $15 \cdot 0060$ & DIGITAL MULTIMETER (GOLDEN CAL) & 345BA OPT OD2 & 17 Feb 2009 & 17Мау2009 \\
\hline
\end{tabular}

Davis Calibration - 2324 Ridgepoint Drive, Suite D - Austin, TX 78754 - Phone: 800-365-0147 - Fax: 512-926-8450

Figure A.7. National Instruments 9217 data-acquisition module calibration sheet II 


\section{Davis Calibration}

Company ID: 229037

NATIONAL INSTRUMENTS

11500 N. MOPAC EXPWY

ATTN. RMA DEPT.

AUSTIN, TX 78759

Instrument ID: 12E9C3E

Manufacturer: NATIONAL INSTRUMENTS

Description: $32-\mathrm{CH} \pm 200 \mathrm{MV}$ TO $\pm 10 \mathrm{~V}, 16-\mathrm{BIT}, 250 \mathrm{KS} / \mathrm{S}$ ANALOG INPUT MODULE

Instrument Identification

\author{
PO Number: 337683
}

\section{Certificate of Calibration}

3214141

CALIDARANON

Certificate Page 1 of 1

Accuracy: Mfr Specifications

\section{Certificate Information}

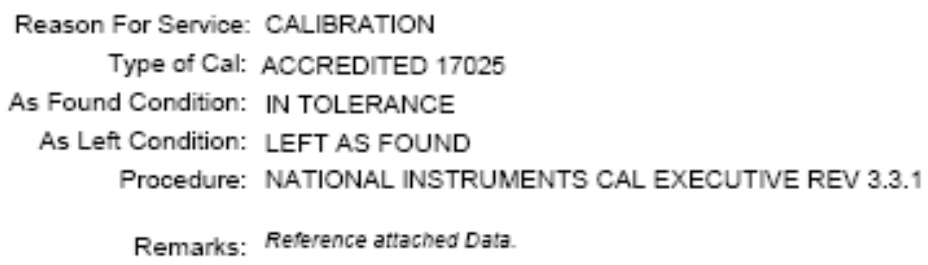

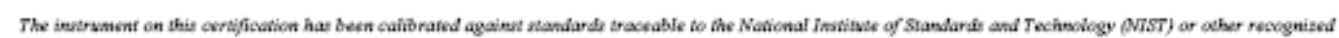

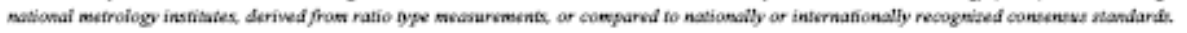

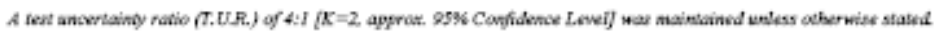

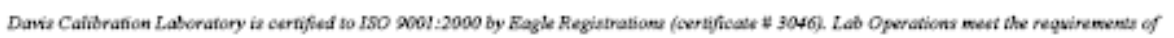

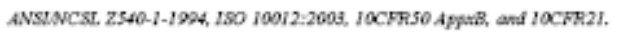

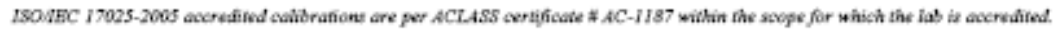

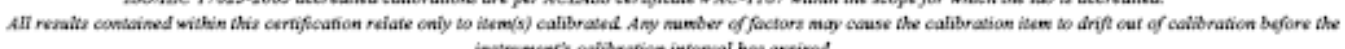
instrament's canidration inferval has expirse.

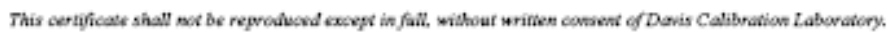

Approved By: VICTOR PENA

Service Representative

\section{Calibration Standards}

$\frac{\text { NIST Traceable\# }}{3143038} \frac{\text { Inst. ID\# }}{15-0271} \quad \frac{\text { Description }}{\text { MULTIFUNCTION CALIBRATOR }} \quad \frac{\text { Model }}{5700 \mathrm{~A}} \frac{\text { Cal Date }}{15 \text { Apr2009 }}$

Davis Calibration - 2324 Ridgepoint Drive, Suite D - Austin, TX 78754 - Phone: 800-365-0147 • Fax: 512-926-8450

Figure A.8. National Instruments 9205 data-acquisition module calibration sheet II 


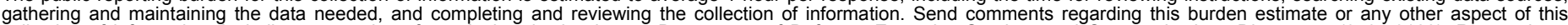

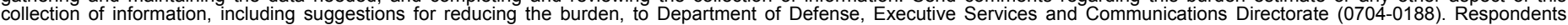

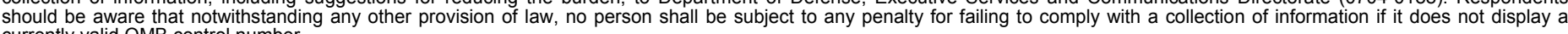

PLEASE DO NOT RETURN YOUR FORM TO THE ABOVE ORGANIZATION.

\begin{tabular}{l|l}
\hline $\begin{array}{l}\text { REPORT DATE (DD-MM-YYYY) } \\
\text { July } 2010\end{array}$ & $\begin{array}{l}\text { 2. } \\
\text { REPORT TYPE } \\
\text { Technical Report }\end{array}$ \\
\hline 4. $\begin{array}{l}\text { TITLE AND SUBTITLE } \\
\text { Wind Turbine Safety and Function Test Report for the Mariah } \\
\text { Windspire Wind Turbine }\end{array}$
\end{tabular}

3. DATES COVERED (From - To)
Wind Turbine Safety and Function Test Report for the Mariah
Windspire Wind Turbine

5a. CONTRACT NUMBER

DE-AC36-08-GO28308

5b. GRANT NUMBER

5c. PROGRAM ELEMENT NUMBER

5d. PROJECT NUMBER

NREL/TP-500-47496

5e. TASK NUMBER

WE10.2211

5f. WORK UNIT NUMBER
7. PERFORMING ORGANIZATION NAME(S) AND ADDRESS(ES)

National Renewable Energy Laboratory

1617 Cole Blvd.

Golden, CO 80401-3393

\section{PERFORMING ORGANIZATION REPORT NUMBER \\ NREL/TP-500-47496}

9. SPONSORING/MONITORING AGENCY NAME(S) AND ADDRESS(ES)

\section{SPONSOR/MONITOR'S ACRONYM(S)} NREL

11. SPONSORING/MONITORING AGENCY REPORT NUMBER

12. DISTRIBUTION AVAILABILITY STATEMENT

National Technical Information Service

U.S. Department of Commerce

5285 Port Royal Road

Springfield, VA 22161

13. SUPPLEMENTARY NOTES

14. ABSTRACT (Maximum 200 Words)

This test was conducted as part of the U.S. Department of Energy's (DOE) Independent Testing project. This project was established to help reduce the barriers to wind energy expansion by providing independent testing results for small wind turbines (SWT). In total, five turbines were tested at the National Wind Technology Center (NWTC) as a part of this project. Safety and function testing is one of up to five tests performed on the turbines, including power performance, duration, noise, and power-quality tests. NWTC testing results provide manufacturers with reports that may be used to meet part of small wind turbine certification requirements. The test equipment includes a Mariah Windspire wind turbine mounted on a monopole tower. L\&E Machine manufactured the turbine in the United States. The inverter was manufactured separately by Technology Driven Products in the United States. The system was installed by the NWTC site operations group with guidance and assistance from Mariah Power.

15. SUBJECT TERMS

wind turbine; Windspire; Independent testing; safety and function test; DOE; small wind turbine certification

\begin{tabular}{|c|c|c|c|c|}
\hline \multicolumn{3}{|c|}{ 16. SECURITY CLASSIFICATION OF: } & \multirow{2}{*}{$\begin{array}{l}\text { 17. LIMITATION } \\
\text { OF ABSTRACT } \\
\text { UL }\end{array}$} & \multirow{2}{*}{$\begin{array}{l}\text { 18. NUMBER } \\
\text { OF PAGES }\end{array}$} \\
\hline $\begin{array}{l}\text { a. REPORT } \\
\text { Unclassified }\end{array}$ & $\begin{array}{l}\text { b. ABSTRACT } \\
\text { Unclassified }\end{array}$ & $\begin{array}{l}\text { c. THIS PAGE } \\
\text { Unclassified }\end{array}$ & & \\
\hline
\end{tabular}

\begin{tabular}{l} 
19a. NAME OF RESPONSIBLE PERSON \\
19b. TELEPHONE NUMBER (Include area code) \\
\hline
\end{tabular}

